\title{
European Storm Petrels Hydrobates pelagicus visiting the Swedish west coast; results from a ringing study 1988-2012
}

\author{
Stormsvalor Hydrobates pelagicus som besöker den svenska Västkusten; resultat \\ från en ringmärkningsstudie 1988-2012
}

KÅRE STRÖM \& AIMON NIKLASSON

\begin{abstract}
The results of a 25 year study of the Storm Petrel Hydrobates pelagicus on the Swedish west coast are described. The first bird was captured on 29 August 1988 (Orust in Bohuslän). A total of 72 Storm Petrels were captured between 1988 and 2012 (64 in Bohuslän and 8 in Halland). Sixty-eight of these were ringed by us and 4 were ringed abroad. Thirteen Storm Petrels $(\sim 18 \%)$ were captured twice or thrice: 4 re-traps by us (ringed abroad, 3 in Norway, 1 in Britain), 2 own re-traps and 6 recaptured abroad ( 2 in Britain and 4 in Norway; one own ringed bird recaptured twice). Three additional birds were spontaneously captured in other studies in southern Sweden during the

same period. Mean body mass (SD) was 25.5 (1.9) g, and wing length was 123.1 (2.6) $\mathrm{mm}$. A concentration of birds during the turn of the millennium may be related to periods of upwelling. Still no birds have been found breeding in Sweden. Comments are made regarding the first description by Linnaeus.

The Storm-petrel Project in Sweden, Kåre Ström, Tvetgatan 277, S-44233, Kungälv, Sweden. E-mail: karestrom@ telia.com

Aimon Niklasson Trolltjärn 18, S-43640, Askim, Sweden E-mail:aimon@bahnhof.se
\end{abstract}

\section{Abstract}

Received 31 December 2013, Accepted 19 April 2014, Editor: Robert Ekblom

\section{Introduction}

The European Storm Petrel Hydrobates pelagicus (hereafter Storm Petrel), is a monogamous colonial seabird usually divided into two different subspecies. The Atlantic population of $H$. p. pelagicus (nominate ssp.) represents $97 \%$ of the world population, mainly breeding in Iceland, Faeroe Islands, the British Isles and Norway. The total population of $H$. p. pelagicus has been estimated at 300,000-680,000 pairs (Mitchell et al. 2004). The other subspecies H. p. melitensis counts only about 10,000 pairs and breeds in the Mediterranean area (Mitchell et al. 2004, Gutierrez et al. 2006). Since the Storm Petrel is nocturnal when arriving or leaving the breeding site (due to predation of gulls or other predators) breeding time and migration has a latitudinal variation. Breeding starts in May in the British Isles but not until August in northern Norway when it is dark enough (Anker-Nilssen \& Anker-Nilssen 1993).

Beside the breeding population there are also a large number of non-breeders moving around in the Atlantic Ocean, because Storm Petrels do not start breeding until 4-5 years old, some breed at other sites and some stop breeding or abandon the egg due to poor conditions. The Storm Petrel can fly more than $350 \mathrm{~km}$ per day and wintering areas are considered to be situated outside West Africa, but wintering is known as south and east as Mozambique, as demonstrated by the recoveries of two birds from Norway (Anker-Nilssen 2000, Bakken 2003). The Storm Petrel is a long-lived bird with ages above 30 years or more (Byrkjeland 1997, Bakken et al. 2003).

Only a few breeding localities are known in Norway and none in Sweden or Denmark. The species is difficult to find and the Norwegian breeding sites have only been known since the 1960s: Röst at Lofoten Islands in the 1960s, Bleiksöya at Vesterålen in 1986, and Erkna close to Ålesund in 1996 (Helling 1962, Barret \& Strann 1987, Olsen 1996, Byrkjeland 1997, Anker-Nilssen 2000).

Before 1988 the Storm Petrel was only observed during stormy weather (wind from the west), mostly during autumn and early winter. Single birds, carried by the wind, have also been found exhausted or dead in areas far from the sea. The Storm Petrel has been found at least 160 times in Sweden since the first finding in 1744-1745 (SOF 1978, 1990, SOF 1993-2012, SOF 2003, and Artportalen 2013). 
This first Swedish record is both remarkable and interesting. The bird was caught alive far from the sea at Hedemora (province of Dalarna) in the middle of Sweden by a hunter, but died soon thereafter. The bird was sent to Carl von Linnaeus who described it as the "Storm-väders-foglen" ("The stormy weather bird"), Procellaria pelagica, in his dissertation Migratiore avium 1745 (Linnaeus 1745) (Figure 1). In 1758 the species got its scientific name, Hydrobates pelagicus (L.), (Brolén \& Lönnberg 1935).

Nearly 100 years passed until the next finding which was made in 1825 in the south of Sweden (province of Skåne). Altogether seven different records were made before 1900, and there were less than 30 accepted records before 1970 (SOF 1990). Nearly all records before 1995 were birds observed

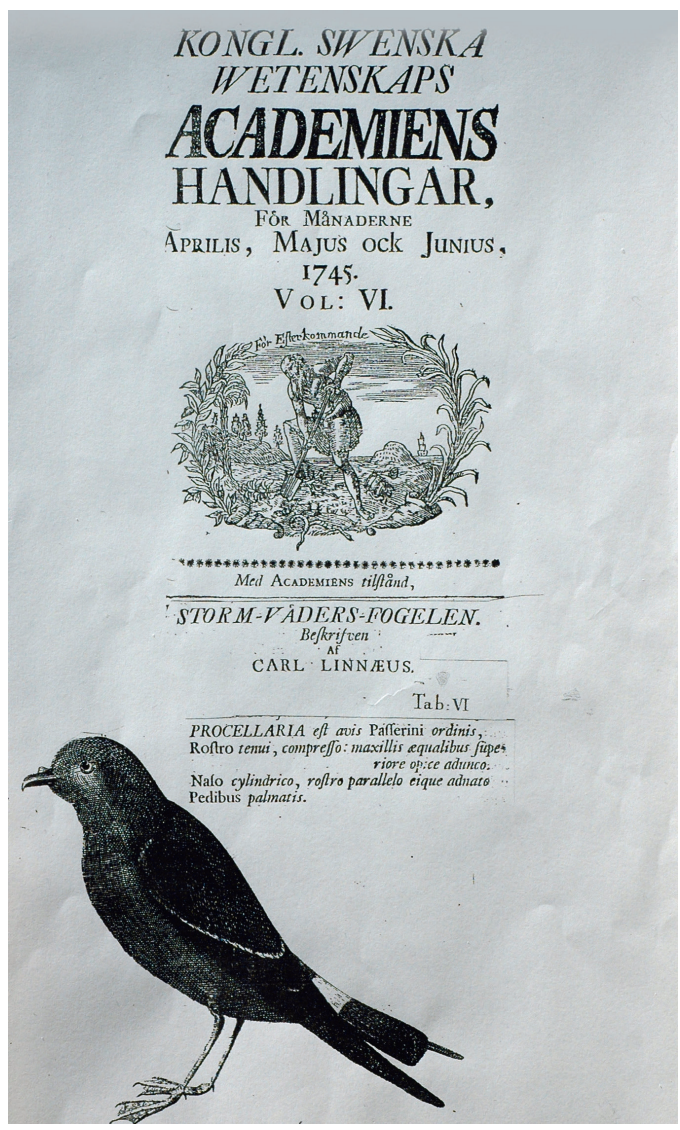

Figure 1. The first description of the Storm Petrel Hydrobates pelagicus (Procellaria) by Carl von Linné (Linnaeus 1745).

Den första beskrivningen av stormsvala Hydrobates pelagicus (Procellaria) av Carl von Linné 1745. during daytime in connection with strong westerly winds. The trapping of a Storm Petrel at Akeröya, Östfold county, Norway, on 30 August 1987 (Viker 1988), near the border in south-east Norway by the late Norwegian ringer Erik Aspegren (Appendix 1), inspired us to try to capture Storm Petrels with mist nets and tape-lures on the Swedish west coast (the Kattegat and the Skagerrak). Some reports from fishermen who had seen Storm Petrels at sea close to the fishing boat and people who believed they had noticed Storm Petrels at lighthouses also awoke our interest. Already at the second trial with tape-luring, a Storm Petrel was caught in a mist net at Hermanö, an island outside Orust in the middle of the province of Bohuslän on 29 August 1988 (Ström \& Börjesson 1988).

The "Storm-petrel Project" was initiated by one of us (KS) and Roland Börjesson (Appendix 2) in order to determine the presence, breeding status and movements of Storm Petrels. Later, other questions were included, such as to find out if the presence of Storm Petrels is linked to periods of upwelling and to determine what are their main areas of origin (Ström \& Niklasson 2005).

Upwelling of water from deeper water layers is a well-known mechanism that has a large influence on hydrographic conditions and marine life along many coasts around the world. The water exchange with the open sea is important for hydrographic conditions and marine life in the coastal zone by bringing in water with different characteristics like salinity, temperature, nutrient content, and plankton fauna and flora. Upwelling areas can attract and aggregate seabirds foraging in these waters (Haney 1985, Adams \& Takekawa 2008 and Wynn \& Kastrel 2012).

The purpose of this study is to show that Storm Petrels not only occur at the Swedish west coast in stormy weather but that they also regularly visit this area during the presumptive breeding time at these latitudes, in July to September (Ström \& Börjesson 1996, Ström 1997, Ström \& Niklasson 2000 and 2005).

\section{Methods}

\section{Localities}

The field work was performed annually since 1988 between the middle of July and the end of September on different islands and peninsulas (Figure 2). Most of the work was performed in two groups of islands in Bohuslän in the Skagerrak part of the coast: near the lighthouse at Måseskär $\left(58^{\circ} 05^{\prime} \mathrm{N}\right.$; 




Figure 2. Ringing localities of the Storm Petrel Project on the Swedish west coast (filled red circles). Other localities where Storm Petrels have been netted unintentionally are shown by black-dotted white circles. The big black dot indicates the approximate finding place of the first Storm Petrel described by Carl von Linné (Linnaeus 1745). The Jutland coastal stream is indicated by a black arrow.

Ringmärkningslokaler $i$ Stormsvaleprojektet på svenska Västkusten (fyllda röda cirklar). Andra lokaler med tillfällig fångst av stormsvala (vita cirklar med svart mitt). Första fyndplatsen för den av Carl von Linné beskrivna stormsvalan anges med stor svart fylld cirkel. Jutska strömmen är markerad med svart pil.

$\left.11^{\circ} 20^{\prime} \mathrm{E}\right)$ and at the "Head" of Hermanö (58 $8^{\circ} \mathrm{N}$; $\left.11^{\circ} 21^{\prime} \mathrm{E}\right)$, Soteskär $\left(58^{\circ} 25^{\prime} \mathrm{N} ; 1^{\circ} 11^{\prime} \mathrm{E}\right)$, Pater Noster $\left(57^{\circ} 53^{\prime} \mathrm{N}\right.$; $\left.11^{\circ} 28^{\prime} \mathrm{E}\right)$ and the group of islands named Väderöarna $\left(58^{\circ} 35^{\prime} \mathrm{N}\right.$; $\left.11^{\circ} 04^{\prime} \mathrm{E}\right)$. In the Kattegat section of the coast the study took place at two peninsulas, Ringhals $\left(57^{\circ} 15^{\prime} \mathrm{N} ; 12^{\circ} 05^{\prime} \mathrm{E}\right)$, and Getterön, (“Gubbanäsan"; 5707’N; $12^{\circ} 12^{\prime} \mathrm{E}$ ). The Bohuslän islands are mostly treeless with gorges, diabase formations and cracks finally formed by the last glacial period. Some small islands in the archipelago of Väderöarna and Soteskär have earlier been the home for small populations of auks like Guillemots Uria aalge and Puffins Fratercula arctica. However, these populations became extinct during the 1960 s, probably due to mink predation and/or the decline of the Atlanto-Scandian herring population. The peninsulas Getterön and Ringhals in the Kattegat are good observation sites for passing seabirds during periods of strong westerly winds (Ström \& Niklasson 2005).

\section{Bird ringing and measurements}

Intentional attempts of mist-netting of Storm Petrels were made each year, usually between 15 July and 30 September and always assisted by tape-lures. In most cases this was done during calm nights with no rainfall close to the sea at sites where rocks and clefts provided a dark background for the nets. In addition to tape-luring we occasionally also spilled fish liver oils close to the nets in order to help attract birds as described by Grubb (1972) and Hutchinson \& Wenzel (1980). Unmarked birds were ringed with rings of stainless steel (Riksmuseum, Stockholm). Most birds were weighed to nearest $0.1 \mathrm{~g}$, and the length of their right wing ("W max", Svensson 2005), tarsus, and, in a few cases, also the tail were measured to the nearest $1.0 \mathrm{~mm}$. In many cases the bill (culmen) and head+bill lengths were measured (to the nearest $0.1 \mathrm{~mm}$ ). Moulting and wearing of the feathers was also studied in order to assess the age of the birds (Scott 1970, Cramp 1977, Ginn \& Melville 1983, Baker 1993 and Bolton \& Thomas 2001). We also recorded if the birds were "playing", that is responded with "purr-call" (song) or "terr-chick call" (flight call) during tape-luring or in net or when ringing the bird (cf. Scott 1970). We also noted if the birds regurgitated oily fluids during the netting and handling. The status of the brood patch was also scored in order to recognize different stages in the brood patch cycle and to help assess if the bird was in an active breeding stage or not. We used three categories for classifying the brood patch: (1) unknown status, (2) immature (occurrence of down, down still left or bare, no down), together with somewhat more developed ("bare, grey and pinkish brood patch"), and (3) mature (well developed red veiny skin or both red veiny and vascularized brood patch) (cf. Scott1970 and Table 2).

\section{Statistics}

Basic statistics were calculated using SAS 6.3. Summary statistics are given as mean, standard deviation, median, range and $95 \%$ confidence limits of the mean (clm95) in some cases together with a t-test. A p-value of $<0.05$ is considered significant. Multiple regression was used to evaluate relationships between body mass and other variables. "True time" (local mean solar time) is calculated as GMT+45 min since Swedish official clock time including summertime is GMT +2 hour and $15 \mathrm{~min}$ for Måseskär (15 minutes corresponds to the longitudinal difference between actual position and time given by the time zone). Time is given when 
bird is taken from net being checked at least every hour.

\section{Other technics and investigations}

In some years we glued small radio transmitters (Holohill, 0.69 gram, www.holohill.com) to the central tail feathers of altogether five Storm Petrels suspected to be breeding birds. The radio signals could be received within $1 \mathrm{~km}$ distance.

We have also been looking for signs of breeding evidence on different islands and coastal sections on the West Coast of Sweden using playback of tape-recordings, playback of Storm Petrel calls next to entrances to potential nest sites during daytime. From 2005, we have basically used the same technology as for the seabird 2000 census 19982002 in the British Isles (Mitchell et al. 2004). The "purr-call" was played for about ten seconds within two meters of potential nest cavities in order to provoke answers from possible breeding birds (Mitchell et al. 2004). We repeated this procedure at least two or three times and were waiting a cou-

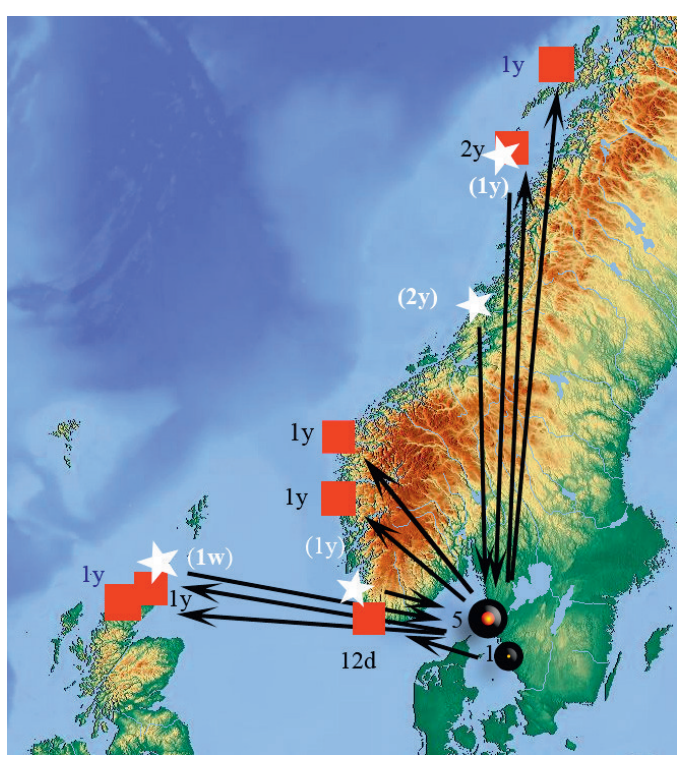

Figure 3. Controls in Sweden of Storm Petrels ringed abroad (white stars). All four birds were controlled at Måseskär (black filled circle). Birds ringed in Sweden and controlled abroad ( 6 birds, 7 localities, red filled squares). Time between ringing and control is indicated in days (d), weeks (w) or years (y).

Kontroller av stormsvalor ringmärkta utanför Sverige (vita stjärnor). Alla fyra fåglarna kontrollerade vid Måseskär (svart fylld cirkel). Lokaler för fäglar märkta i Sverige och återfångade utomlands (6 fåglar, 7 lokaler, röda fyllda fyrkanter). Tidsavstånd i dagar (d), veckor (w) eller år (y). ple of minutes for possible answer. We also played the nestling's "begging" sound in the same way at potential breeding grounds for possible responses from crevices, boulders, and other structures. We have also used advanced listening devices with sensitive microphones at such sites. From around 2005 the Storm-petrel Project was concentrated to Måseskär and a few other islands in Bohuslän.

Fish-oil was been used on some occasions to attract Storm Petrels, since they are known to have a good developed sense of smell (Grubb 1972, Hutchinsson \& Wenzel 1980). It has even been described as a way fishermen caught Storm Petrels for use as bait.

Meteorological data like temperature, wind, moon cycle and upwelling for the period 19972012 were provided by SMHI, the Swedish Meteorological and Hydrological Institute. SMHI has long time series on the Swedish west coast of wind data, coastal stratification and upwelling on day to day basis (Björk \& Nordberg 2003, SMHI 2012).

\section{Results}

Numbers captured

A total of 72 Storm Petrels were captured on the Swedish west coast during the project period, 1988-2012. Out of these, 68 birds were ringed

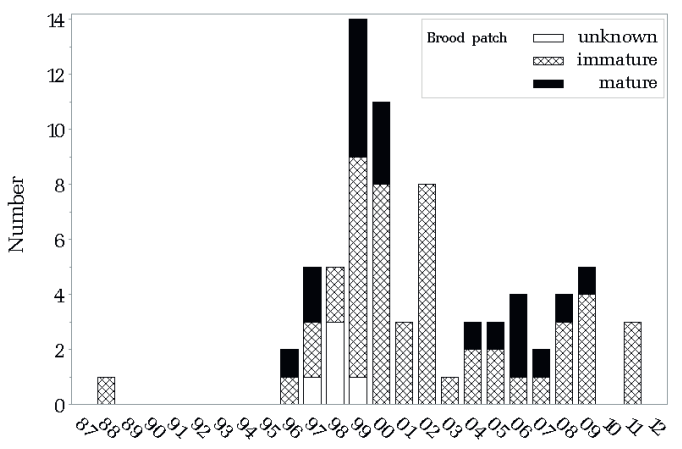

Figure 4. Number of Storm Petrels netted on the Swedish west coast by year and maturity of the brood patch. The pattern in the histogram reflects the maturity of the brood patch (black indicate "potential breeders" or individuals who have reached breeding age and are in an active breeding period). Two own re-traps are included, one in $1999(\mathrm{n}=74)$.

Antal stormsvalor som nätfångats på svenska Västkusten under olika år och i förhållande till ruvfläckens utvecklingsstadium (mognad). Mönstret i staplarna indikerar graden av denna (svart färg indikerar "potentiella häckande fåglar" eller fåglar som uppnått häckningsåldern och befinner sig $i$ aktiv häckningsfas). Två återfångade egna märkta fåglar ingår, varav en $1999(n=74)$. 


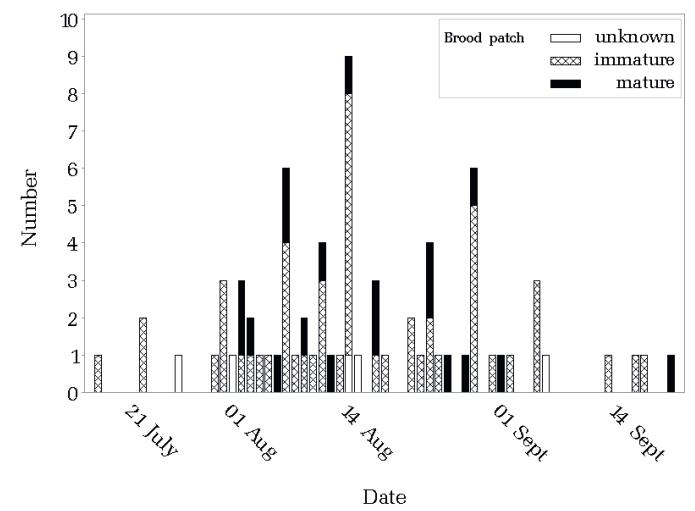

Figure 5. Number of Storm Petrels netted on the Swedish west coast in relation to time of the year and maturity of the brood patch. Two own re-traps are included $(n=74)$. Symbols as in Figure 4.

Antal nätfångade stormsvalor på svenska Västkusten i förhållande till tid på året och ruvfläckens mognad. Två återfångade egna märkta fåglar ingår $(n=74)$. Symboler som $i$ Figur 4.

by the Storm Petrel Project, 60 in Bohuslän and 8 in Halland. The remaining four individuals were already ringed, three in Norway and one in Scotland (Figure 3). We recaptured two of the birds we ringed on the same or close to the same location. Notably, three other Storm Petrels were unintentionally caught in the Baltic Sea in southern Sweden, one in 1990 at Utklippan Bird Observatory $\left(55^{\circ} 57^{\prime} \mathrm{N}, 15^{\circ} 42^{\prime} \mathrm{E}\right)$ in Blekinge 1990 , and two, in 2008 and 2010, during ringing of Common Terns

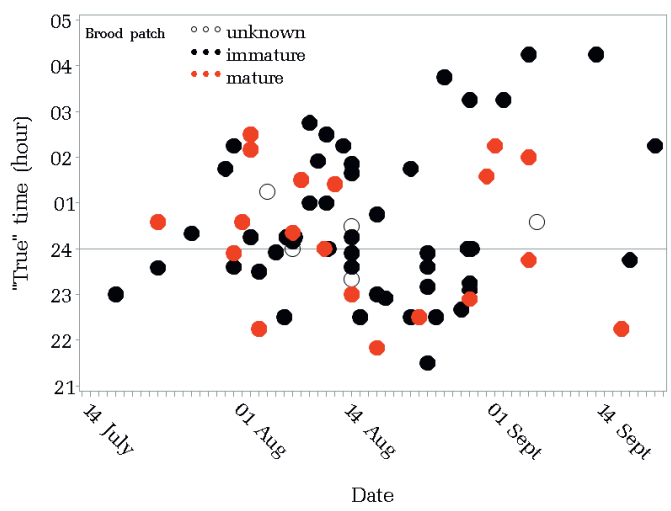

Figure 6. "True" time (local mean solar time, see methods) for netted Storm Petrels on the Swedish west coast in relation to maturity of the brood patch and time of the year .Two own re-traps are included $(\mathrm{n}=74)$.

"Sann" tid (lokal medelsoltid, se metoder) för nätfångade stormsvalor på svenska Västkusten i förhållande till ruvfläckens mognad och tid på året. Två återfångade egna märkta fåglar ingår $(n=74)$.
Sterna hirundo at Sandön $\left(56^{\circ} 13^{\prime} \mathrm{E}, 12^{\circ} 46^{\prime} \mathrm{E}\right)$ in Kattegat in southwest of Sweden. We caught only one Storm Petrel between 1988 and 1995, which we consider was due to poor trapping techniques and equipment during the first years of our project. Since 1996, the tape-luring was significantly improved with better nets, more sophisticated recording and playback equipment, and better sound recordings. There was a peak in capture rate of Storm Petrels in 1998-2002 (Figure 4), which at least for 1998-1999 might have been linked with periods of up-welling in the Kattegat and the Skagerrak. The mean capture success over the 25-year study period was 0,374 birds per night or about three per year (74 catches during 198 nights).

\section{Timing of the captures}

The earliest capture was made on 18 July (1999) and the latest on 17 September (2000), but too few attempts were made outside the main capture period (15 July - 30 September) to exclude the presence of Storm Petrels earlier or later in the season (Figure 5). Most captures were made within two hours of true midnight (Figure 6).



Figure 7. Relationship between body mass (BM) and wing length (WL) of 67 different Storm Petrels netted on the Swedish west coast $\left(B M=-14.65+0.327 * W L, r^{2}=0.19, p<0.0002\right.$, each individual measured once). Broken lines indicate $95 \%$ confidence limits of the mean regression line for all birds regardless of maturity (red filled circle indicate potential breeders or individuals who have reached breeding age and are in an active breeding period).

Förhållande mellan vikt och längd hos 67 stormsvalor nätfångade på den svenska Västkusten.

(Vikt $=-14,65+0,327 *$ Vinglängd, $r^{2}=0,19 p<0,0002$, en mätning per individ). Streckad linje visar $95 \%$ konfidensintervall för regressionslinjens medelvärde (röd färg indikerar potentiella häckande fåglar eller fåglar som uppnått häckningsåldern och befinner sig $i$ aktiv häckningsfas). 
Table 1a. Biometric data for 72 Storm Petrels captured on the Swedish west coast 1988-2012.

Biometriska data för 72 stormsvalor fångade på svenska Västkusten 1988-2012.

\begin{tabular}{lcccccc}
\hline Variable & $\mathrm{N}$ & Mean & Median & SD & Min & Max \\
\hline $\begin{array}{l}\text { Wing length mm } \\
\text { Vinglängd }\end{array}$ & 71 & 123.1 & 123.0 & 2.6 & 117.0 & 130.0 \\
$\begin{array}{l}\text { Bill length mm } \\
\text { Näbblängd }\end{array}$ & 43 & 11.5 & 11.5 & 0.7 & 10.1 & 13.6 \\
$\begin{array}{l}\text { Head+Bill length mm } \\
\text { Huvud+Näbb längd }\end{array}$ & 55 & 31.8 & 32.0 & 0.7 & 28.5 & 33.3 \\
$\begin{array}{l}\text { Tarsus length mm } \\
\text { Tarslängd }\end{array}$ & 60 & 22.9 & 22.9 & 0.8 & 20.8 & 24.9 \\
$\begin{array}{l}\text { Tail length mm } \\
\begin{array}{l}\text { Stjärtlängd } \\
\text { Body mass g }\end{array}\end{array}$ & 14 & 58.4 & 58.5 & 2.8 & 54.0 & 62.0 \\
Kroppsmassa & 67 & 25.5 & 25.3 & 1.9 & 21.1 & 31.5 \\
\hline
\end{tabular}

Table 1b. Biometric data, in two age groups, for 72 Storm Petrels captured on the Swedish west coast in 19882012.

Biometriska data, i två åldersgruper, hos 72 stormsvalor fångade på svenska Västkusten 1988-2012. För variablerna på svenska, se Tabell 1a.

\begin{tabular}{ccrrrrr}
\hline $\begin{array}{l}\text { Age group and variable } \\
\text { Aldersgrupp och variabel }\end{array}$ & $\mathrm{N}$ & Mean & SD & $\begin{array}{r}\text { Confidence } \\
\text { interval (95\%) }\end{array}$ & Min & Max \\
\hline Age Alder 2K+ & 32 & 122.8 & 2.6 & $121.8-123.7$ & 117.0 & 127.5 \\
Wing length mm & 21 & 23.0 & 0.9 & $22.6-23.4$ & 21.0 & 24.9 \\
Tarsus length mm & 30 & 25.5 & 2.0 & $24.8-26.3$ & 21.1 & 30.5 \\
Body mass g & & & & & & \\
\hline Age Alder 3K+ & 39 & 123.4 & 2.5 & $122.6-124.2$ & 117.0 & 130.0 \\
Wing length mm & 39 & 22.8 & 0.7 & $22.6-23.0$ & 20.8 & 24.0 \\
Tarsus length mm & 37 & 25.5 & 1.8 & $24.9-26.1$ & 22.6 & 31.5 \\
Body mass g & & & & &
\end{tabular}

The weather was a major limiting factor during some years, when long periods of low pressure and unstable weather resulted in fewer capture opportunities than planned. One example is the 2010 season when catch efforts could only be made at three different occasions.

\section{Size measurements}

The mean wing length of all individuals measured was $123.1 \mathrm{~mm}(\mathrm{n}=71, \mathrm{SD}=2.6$; Table 1a). There was no significant difference in wing length between individuals classified as $2+$ and $3+$ calendar year birds ( $\mathrm{t}$-test, $\mathrm{t}=0.98, \mathrm{df}=69, \mathrm{p}=0.33$; Table $1 \mathrm{~b}$ ).

The body mass ranged between 21.1 and 31.5 g (mean 25.5 g, SD 1.9, n=68; Table 1a) with no statistical significant difference between the age groups (t-test, $\mathrm{t}=0.09, \mathrm{df}=65, \mathrm{p}=0.93$; Table $1 \mathrm{~b}$ ). The high body mass in some birds could not be explained by body size expressed by wing length, which only explained $19 \%$ of the variation in body mass (regression test $\mathrm{F}=16.1, \mathrm{r} 2=0.19, \mathrm{df}=66$, $\mathrm{p}=0.0002$; Figure 7). We found no significant differences in tarsus measurements between age categories ( $\mathrm{t}$-test, $\mathrm{t}=1.06, \mathrm{df}=58, \mathrm{p}=0.29$ ), or other measurements (Table 1a and 1b).

\section{Other variables of birds captured}

Some additional observations are given in Table 2. Nineteen $(27.5 \%)$ of 69 individuals examined had a "mature" and "well-developed" reddish bare and veiny brood patch (a few brood patches even "vascularized") without down. Fifty-two (75\%) of 69 tape-lured individuals produced a sound when trapped in the net or during subsequent handling. Twenty-seven (39\%) of 69 individuals regurgitated food at capture or during later handling. In all cases this was an oily orange-colored liquid smelling like fish-oil. 
Table 2. Distribution of the 74 Storm Petrels (including 2 own retraps) captured on the Swedish west coast in 1988-2012 in relation to some criteria that might suggest breeding (see text for details).

Fördelning av 74 stormsvalor (inklusive 2 egna återfångade individer) fångade på svenska Västkusten 19882012 i relation till några kriterier som skulle kunna indikera häckning (se text för detaljer).

\begin{tabular}{lrrrr}
\hline Criterium & \multicolumn{3}{c}{ Age group Aldersgrupp } \\
\cline { 2 - 5 } & $?$ & $2 \mathrm{~K}+$ & $3 \mathrm{~K}+$ & Total \\
\hline $\mathrm{N}$ (all birds included alla fåglar medräknade) & 0 & 45 & 29 & 74 \\
$\mathrm{~N}$ (excluding 2 own controls exclusive 2 egna kontroller) & 0 & 45 & 27 & 72 \\
Calls Läten & 5 & 25 & 27 & 52 \\
Regurgitation Uppstötning & 5 & 12 & 15 & 27 \\
Fully developed brood patch Fullt utvecklad ruvfläck & 5 & 10 & 9 & 19 \\
Body mass >27 g Kroppsmassa $>27$ g & 6 & 7 & 7 & 14 \\
\hline
\end{tabular}

\section{Radio transmitters mm.}

The radio transmission technology was not successful and was given up 2004. When releasing the birds after ringing we could only follow one or two birds and the flight direction up to half a minute and found no indication of birds breeding or occupying a burrow in the investigation area. It put great demands on the detection operations at night and the transmission signals has clear limitations in space and time. One of the radio-tagged Storm Petrels on Måseskär was checked nearly a year later on the west coast of Norway, at Fedje in Hordaland, and appeared to be in good condition. The antenna equipped radio transmitter was still in place on the un-moulted central tail feathers.

\section{Listening and playback at potential nesting habitats}

Playback using "Purr- or churr- sound" at potential nest sites or nesting habitats on different islands in the archipelago in Bohuslän was tested from 2005 but gave no positive results. Similarly, the playback of "begging" sound of nestlings did not provoke any audible responses from rock crevices or cavities in the ground. Nor did the use of sensitive microphones at potential nest sites on some islands detect any signs of birds.

\section{Use of fish oil}

We found no increase in capture rates of Storm Petrels since we started to use fish oil spilled on the ground close to the nets, but have no control group for comparison.

\section{Recoveries}

We have captured four Storm Petrels ringed abroad, three in Norway and one in UK (Figure 3). As we have two recoveries of birds that we have ringed ourselves, $8 \%$ of the birds captured on the Swedish west coast have been ringed (6 of 72). This is in accordance with some Norwegian ratings (8.1 to $12 \%$; Byrkjeland 1997, Bakken et al. 2003) in spite of our small material. When including also 6 birds ringed by us, but recaptured abroad, the recovery rate was about $18 \%$ (13 of 72 , when including one bird recaptured twice) (cf. Byrkjeland 1997, Bakken et al. 2003, Naturhistoriska riksmuseet 1988-2012).

One of the birds from Norway was ringed at Klepp, in Rogaland (58 $55^{\circ} \mathrm{N}$; $05^{\circ} 30^{\prime} \mathrm{E}$ ) in southern Norway, one in central Norway, in Namsos in Nordtröndelag $\left(64^{\circ} 37^{\prime} \mathrm{N} 11^{\circ} 02^{\prime} \mathrm{E}\right)$ and one at Hernyken in Röst the outermost part of the Lofoten Islands $\left(67^{\circ} 26^{\prime} \mathrm{N} 11^{\circ} 52^{\prime} \mathrm{E}\right)$. All these birds were caught at Måseskär (Sweden) and the distance to Röst is $1038 \mathrm{~km}$. The last bird was checked a month later, farther north in Norway, at Hovden in Vesterålen in Nordland (68 $\left.47^{\circ} \mathrm{N} 14^{\circ} 32^{\prime} \mathrm{E}\right)$.

The Storm Petrel from Britain was ringed on 27 July 2006 on Sanday, Orkney (59 $13^{\prime}$ N 02 $30^{\circ}$ 'E) and was controlled at Måseskär nine days later.

Officially six Storm Petrels ringed at the Swedish west coast, all at Måseskär, were recaptured abroad, four in Norway (one bird recaptured twice) and two in the British Isles (Figure 3). Two of the birds were captured in northern Norway, at Fuglenyken in Nordland (67 $47^{\prime} \mathrm{N}$; $\left.14^{\circ} 26^{\prime} \mathrm{E}\right), 1200 \mathrm{~km}$ north of Måseskär, and one at Hernyken (see above). Two birds were recaptured in southern Norway, at Fedje in Hordaland $\left(60^{\circ} 46^{\prime} \mathrm{N} 04^{\circ} 42^{\prime} \mathrm{E}\right)$ and at Eigersund in Sor-Rogaland $\left(58^{\circ} 22^{\prime} \mathrm{N} 06^{\circ} 03^{\prime} \mathrm{E}\right)$.

The Storm Petrel recaptured at Hernyken had two years earlier (one month after time of ringing) 
been recaptured at Kråkenes in central Norway, but the ring number was wrongly read (figure 6 read as 9 , a ring at that time not yet used). It is therefore not registered as an official record. The last two birds were recaptured in Scotland, at Faraid Head (58.36N 04.47E) in the Highland Region, and on Sanday in Orkney (see above) (Figure 3). One of the Storm Petrels, ringed at Måseskär in 1999, was recaptured almost a year later on the little island Torsö in the Väderöarna archipelago, whereas one ringed on the west side of Måseskär in 2009 was recaptured only a few hours later in a mist-net on the north side of the island. Three birds have been caught three times, including the misread record in Norway (Figure 8).

\section{Discussion}

During the 25 years of the Storm Petrel Project we demonstrated that Storm Petrels regularly visit the Swedish west coast at night during the presumptive breeding time at this latitudes, in contrast to winddriven birds occasionally found inland like the one first described by Linnaeus (1745). The species' avoidance of moving in coastal areas at day-time is considered to be an adaption to predation by gulls,



Figure 8. Three Storm Petrels netted on Måseskär by the Swedish Storm Petrel Project and ringed or re-trapped on two other different localities. The plots for each bird are connected with arrows of the same colour.

Tre stormsvalor nätfångade på Måseskär $i$ "Stormsvaleprojektet”" och som märkts eller återfångats på två andra lokaler. Varje fågel sammanbinds med pilar av samma färg. and to prey moving to the surface at night. They are also known to travel long distances in a short time, even within the breeding season (Scott 1970, Anker-Nilssen 2000, Bakken et al. 2003).

The high body mass and well-developed brood patch exhibited by some of the netted birds might suggest that some birds were active breeders, but high body mass could also well be explained by good food supply in the area. This type of brood patch could resemble the stages named highly vascularized with systems of dilated blood vessels (vi) and greatly distended blood vessels with knotted appearance (type vii) by Scott (1970) in his thesis, indicating that these individuals have reached breeding age and that they have just left the nest cavities and are in an active breeding period.

Nevertheless, it is difficult to determine whether tape-lured, mist-netted Storm Petrels with red, veiny featherless brood patches are sexually mature birds or if they are non-breeding wandering birds. According to Scott, no bird with these criteria can be classified as a nesting bird, but it is an indication of a bird possessing a cavity at a breeding site (Scott 1970). Non-breeding wandering individuals may also occur at breeding sites in the breeding season and non-breeding birds can also display a red veiny nude brood patch. Storm Petrels also move rapidly over great distances at their foraging (Scott 1970). Immature birds are also reported to be easier to catch (Harris et al. 1993). Most British Storm Petrels are ringed as sound-lured, wandering, immature birds when between two and five years old when studying the recapture rate of birds ringed as chicks (Okill \& Bolton 2005). The decline in recapture rate reflects losses from the wandering population due to both mortality and recruitment as breeding adults.

The mean weight was in accordance with that of a breeding population in England, $25.4 \mathrm{~g}$ (Cramp $1977, \mathrm{n}=62$ ). On the other hand, in Scott's studies in 1970 at Skokholm ( $\mathrm{n}=6856$, July-September), the average weight was $27.3 \mathrm{~g}(\mathrm{sd}=2.6)$ for all birds (27.6 $\mathrm{g}$ for adult breeders and at least $2 / 3$ of all birds) and $25.3 \mathrm{~g}$ for non-breeders. For adult birds there was a continuous reduction of weight from May (30 to $26.7 \mathrm{~g}$ ) until late September, which could not be found in our own material.

Måseskär is strategically placed where the eastbound Jutland current (Jutska strömmen) approaches the coast and meets the northbound Baltic current, running close to the coast. The island lies in a nutrient- and fish-rich coastal area, which at times is likely to attract foraging Storm Petrels. In Skagerak significantly more Fulmars 


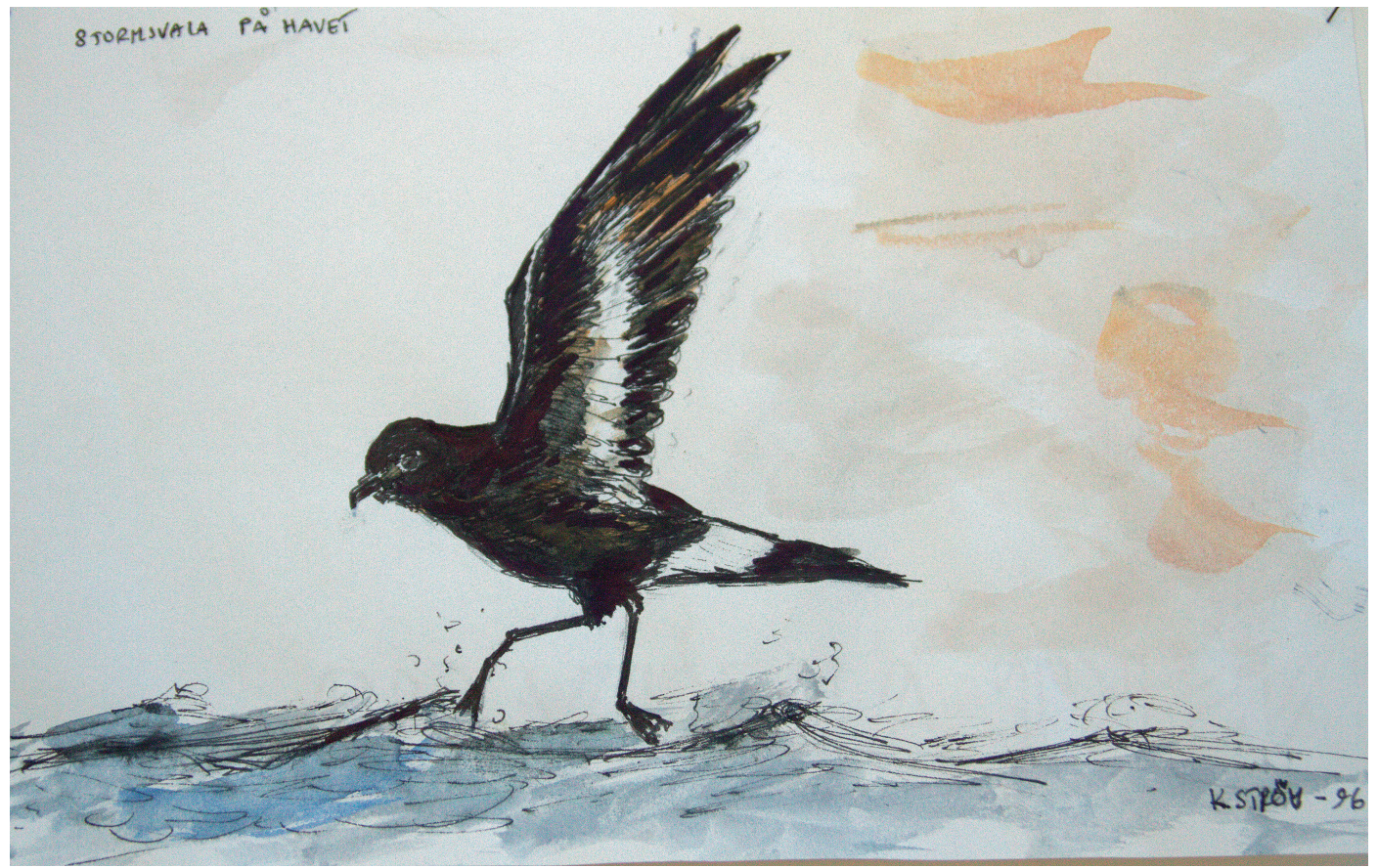

Watercolours and ink. Vattenfärger och bläck. Kåre Ström 1996.

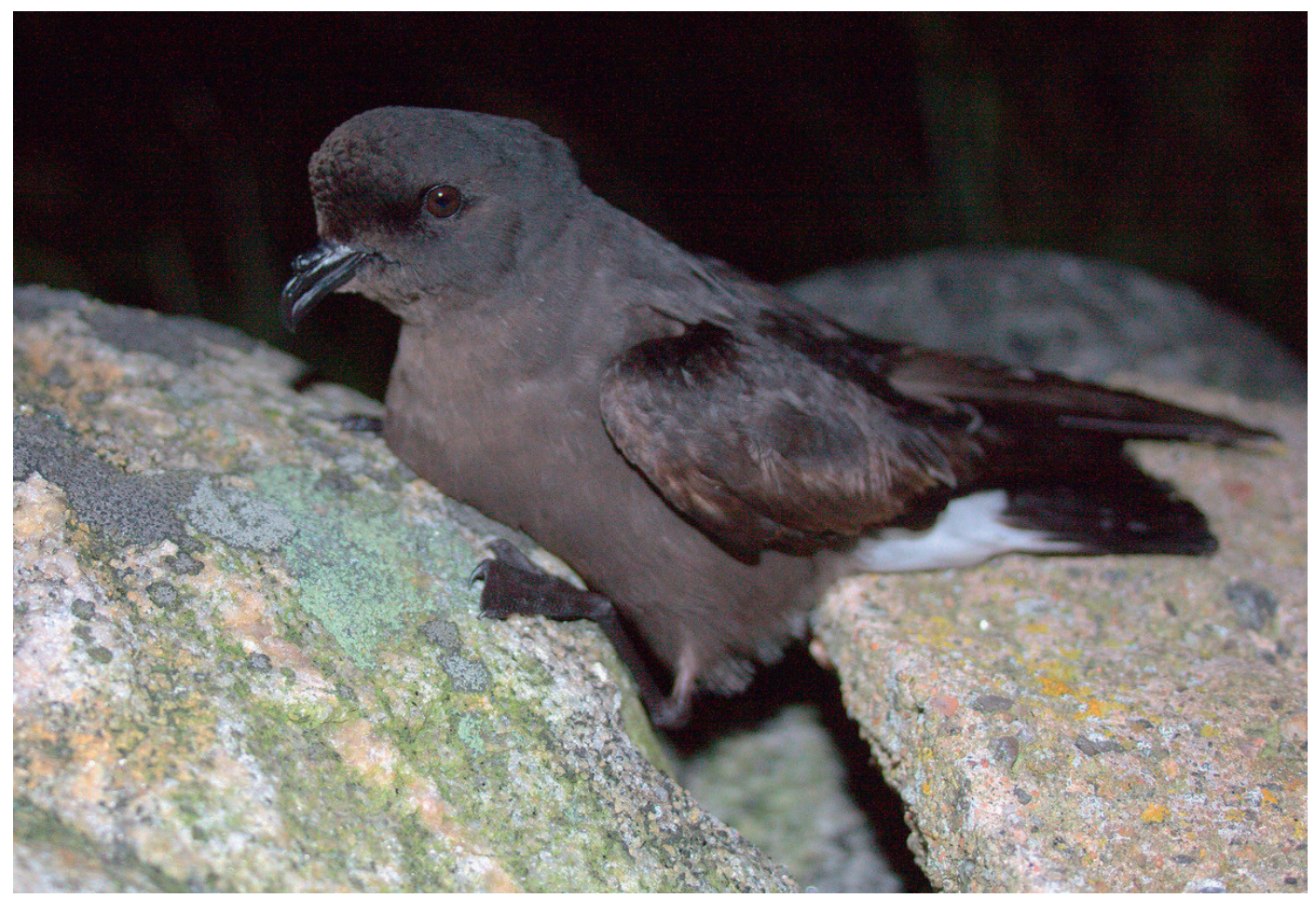

Storm Petrel ringed at Nidingen 23 July 2011. Photo Kåre Ström. 
Fulmarus glacialis and Little Auks Alle alle were found in upwelling areas under certain hydrological conditions and different times of the year (Skov \& Durinck 2000). It is well-known that seabirds like petrels, are attracted to upwelling areas where cooler subsurface and nutrient rich water is drawn toward the surface and concentrate zooplankton and small prey fish in the upwelling zone (Hanley 1985, Adams \& Takekawa 2008, Wynn \& Kastrel 2012). Between 1988 and 2012 maximum number of captured Storm Petrels was reached in 1999 (13 birds). Increased periods of upwelling were also registered this year in Skagerak and Kattegat (SMHI 2012).

It is well known that Storm Petrels can move rapidly long distances between different coastal localities for foraging, (in Norway $>10 \mathrm{~km} / \mathrm{h}$ up to $360 \mathrm{~km}$ in 24 hours; Byrkjeland 1997, Bakken et al. 2003, Anker-Nilssen 2000).

Our study, like others, shows that Storm Petrels are attracted by playback of their calls and also react with different answering calls. Enhanced playback of "churring song" attracts Storm Petrels to the netting area and subsequently into the net as shown in a number of different studies (Scott 1970, Mitchell et al. 2004). In order to take advantage of the Storm Petrels' sense of smell of natural oil substances (Grubb 1972, Hutchinson \& Wenzel 1980) we briefly tested this method with no obvious success. Although we tried many different technics used in other studies (cf. Mitchell et al. 2004), we found no evidence of breeding birds.

The average wing length $(123.1 \mathrm{~mm})$, in our study (W "max", Svensson 2005), was significantly longer than in several other studies. It can be compared with the mean length $120.0 \mathrm{~mm}(\mathrm{sd}=2.2$ $\mathrm{n}=1302)$ for breeding adults and $119.2 \mathrm{~mm}(\mathrm{sd}=2.6$ $\mathrm{n}=1010$ ) for first-season non-breeders in Skokholm (Scott 1970), $120 \mathrm{~mm}$ in the British Isles (Cramp $1977)$ and $123.5 \mathrm{~mm}(\mathrm{sd}=3.1 ; \mathrm{n}=22)$ in August and $121.81(\mathrm{sd}=1.9, \mathrm{n}=27) \mathrm{mm}$ in October at Hernyken in Lofoten (Aarvak \& Öien 2005). The differences indicated above may well be significantly biased by different methods, although they can suggest a latitudinal increase in size, which appears to be valid for most bird species (Meiri \& Dayan 2003). We found no significant difference between age groups in our material, although the samples were rather small in comparison and certainly not mutually exclusive. Referring to Scott (1970) the longest winglengths would appear in category $3+$. He stated in his study that two or three year old birds have not yet attained full growth and even not reached the adult wing length (on average $0.82 \mathrm{~mm}$ shorter).

\section{Conclusion}

We found no evidence of nesting on the west coast of Sweden, although Storm Petrels appear at night during the presumptive breeding season in JulySeptember. We cannot, however, exclude that breeding could occur in some years with extremely favourable conditions during long periods of upwelling and occurrence of nutrient-rich cold water from the ocean currents. Notably, Storm Petrels are seen in day-time during stormy weather, especially in autumn (a total of 160 sightings in Sweden). However, our results show that there is a regular occurrence of Storm Petrels on the Swedish west coast from the middle of July to late September.

\section{Aknowledgement}

We are most grateful to all those dedicated persons who have supported and participated in the project the Storm-petrel Project in Sweden, especially with technical support, transportation and accommodation. Special thanks to the late Erik Aspegren in Norway who inspired us to start the Swedish project and who invited us to study and ring Storm Petrels at Hernyken in the Lofoten Islands. Special thanks also to late Hugo Andersson for technical support and to late Roland Börjesson who with indefatigable enthusiasm participated from the start in 1988. Special thanks also to Mikael Nord and Roland Asteling who participated in the project by ringing at Ringhals and Gubbanäsan in Halland. Special thanks also to Stina and Folke Sjöberg from Käringön and to late Leif Lehmann from "Stiftelsen Måseskärs vänner" who made possible all the return transportations and accomodation at the Måseskär lighthouse. Warm thanks also to Karl-Allan Nordblom, Leif Dahlström, Jan Artursson, Dan Lundberg, Carl-Ivar Hagman, Lennart Tullberg, Thomas Carlsson, Lennart Elg, Peter Strandvik, Nils Abrahamsson, Stefan Oskarsson, Raimo Niklasson, Christer Hjelmsten, Matti Åhlund and to the late Bruno Sundin and also many other people who participated in the project and helped with transportation to different islands, important information and accommodation. We are also grateful to GOF and SOF for support from different foundations, to the Bird Ringing Centre in Sweden and to the County Administrative Board for permission to perform the project and to make temporary visits in certain islands among others Soteskär and Väderöarna. Finally we are very grateful for invaluable comments from two unknown reviewers. 


\section{References}

Aarvak, T. \& Öien, I.J. 2005. Kartlegging av hekkende havsvaler og stormsvaler på Hernykken, Röst, oktober 2005. NOF rapport $n r$. 2-2005. Norsk Ornitologisk Forening, Trondheim.

Adams, J.K. \& Takekawa, J.Y. 2008. At-sea distribution of radio-marked Ashy Storm-Petrels Oceanodroma homochroa captured on the California Channel Islands. Marine Ornithology 36: 9-17.

Anker-Nilssen, T. \& Anker-Nilssen, P. 1993. Breeding of Leach's Petrel Oceanodroma leucorrhoa in the Röst archipelago. Fauna norv. Ser C. Cinclus 16: 19-24

Anker-Nilsen, T. 2000. European Storm Petrel, Hydrobates pelagicus. In Anker-Nilssen, T., Bakken, V., Ström, H., Golovkin, A.N., Bianki, V. V. \& Tatarinkova, I. P. (eds). Rapport The Status of Marine Birds Breeding in the Barent Sea Region, Rapport 113, Norwegian Polar Institute, Tromsö.

Artportalen 2013. Http://svalan.artdata.slu.se/birds/. Rapporterade stormsvalor 1900-2012. Sveriges Lantbruksuniversitet (SLU) \& Sveriges Ornitologiska Förening (SOF)

Baker, J.K. 1993. Identification Guide to European NonPasserines. BTO Guide 24, The British Trust for Ornithology. Thetford.

Bakken, V., Runde, O. \& Tjörve, E. 2003. Norsk Ringmerkingsatlas, Volym I. Stavanger Museum, Norge.

Barett, R.T. \& Strann, K.-B. 1987. Two new breeding records of the Storm Petrel, Hydrobates pelagicus in Norway. Fauna norv. Ser. C, Cinclus 4: 115-116.

Björk, G. \& Nordberg, K. 2003. Upwelling along the Swedish west coast during the $20^{\text {th }}$ century. Continental Shelf Research 23: 1143-1149.

Bolton, M. \& Thomas, R. 2001. Moult and ageing of Storm Petrels, Hydrobates pelagicus. Ringing and Migration 20: 193-201.

Brolén, C.A. \& Lönnberg E. 1935. Linnés avhandling i Migrationes Avium 1757. SLÅ 18: 23-58.

Byrkjeland, S. 1997. Stadig gåtefull og lyssky. Vår Fuglefauna 20(3): 113-116.

Cramp, S. (ed.) 1977. Birds of the Western Paleartic. Vol. I. Oxford University Press, Oxford.

Ginn, H.B. \& Melville D.S. 1983. Moult in Birds. BTO GUIDE 19. The British Trust for Ornithology. Thetford.

Grubb, T. 1972. Smelling and foraging in Petrels and Shearwaters. Nature 237: 404-405.

Gutiérrez, R., López, F., Ramal A. \& Guinart, E. 2006. Coastal Mediterranean Storm Petrel Hydrobates pelagicus populations: isolated small breeding sites or outlying subcolonies of larger breeding colonies? Atlantic Seabirds 8(1/2): 31-40.

Haney, J.C. 1985. Petrel occurences in relation to uppwelling off the coast of the Southeastern United States. The Wilson Bulletin 97(4): 543-547.

Harris, P., Fowler, J.A. \& Okill J. D. 1993. Initial results of Storm Petrel, Hydrobates pelagicus, ringing in Portugal. Ringing and Migration 14: 133-134.

Helling, A. 1962. Stormsvaler hekker på Röst. Sterna 5:4144.

Hutchinson, L. \& \& Wenzel, B. 1980. Olfactory guidance in foraging by Procellariformes, Condor 82: 314-319.

Linnaeus, C. 1745. Storm-väders-Fogelen. Kungliga Swenska Wetenskaps Academiens Handlingar 1745, Vol. VI.
Meiri, S. \& Dayan, T. 2003. On the validity of Bergmann's rule. Journal of Biogeography 30: 331-351.

Mitchell, P., Newton, F., Ratcliffe, N. \& Dunn, T. E. 2004. Seabird Populations of Britain and Ireland. Poyser, London.

Okill, J.D. \& Bolton, M. 2005. Ages of the Storm Petrels Hydrobates pelagicus prospecting potential breeding colonies. Ringing \& Migration 22: 205-208.

Olsen, O. 1996. Hekkefun av havsvale og stormsvale på Möre-kysten. Vår Fuglefauna 19: 169-171.

SAS 9.3 SAS, Institute Inc., Cary, NC, USA.

Scott, D. A. 1970. The breeding biology of the Storm Petrel Hydrobates pelagicus. Unpublished D. Phil. Thesis. University of Oxford.

Skov, H. \& Durinck, J. 2000. Seabird distribution in relation to hydrography in the Skagerak. Continental Shelf Research 20: 169-187.

SMHI 2012. Uppgifter över perioder med "upwelling” i Kattegatt och Skagerack 1997-2012.

Sveriges Ornitologiska Förening (SOF) 1978. Sveriges Fåglar. Stockholm.

Sveriges Ornitologiska Förening (SOF) 1990. Sällsynta fåglar i Sverige, Vår Fågelvärld, supplement 13.

Sveriges Ornitologiska Förening 1993-2012. Fågelåret 1993-2012.

Sveriges Ornitologiska Förening 2003. Sällsynta fåglar $i$ Sverige. 2:a uppl Stockholm.

Ström, K. \& Börjesson, R. 1988. Häckar stormsvalan i Bohuslän? Fåglar på Västkusten 22: 119-120.

Ström, K. \& Börjesson, R. 1996. Stormsvalefångst under häckningstid på Västkusten. Fåglar på Västkusten 30: 228-233.

Ström, K. 1997. Projekt stormsvala. Vår Fågelvärld 7: 3839.

Ström, K. \& Niklasson, A. 2000. Stormsvalorna, Hydrobates pelagicus, på Västkusten. Häckande eller icke häckande fåglar? Fåglar på Västkusten 34: 57-60.

Ström, K. \& Niklasson A. 2005. Stormsvala på Västkusten, en svensk häckfågel? Vår Fågelvärd 64(8): 8-19.

Svensson, L. 2005. Identification Guide to European Passerines. Fourth edition. Stockholm.

Viker, M.G. 1988. Ornitologiske observasjoner i Östfold. Nytt fra lokale rapport- og sjeldenhetskomiteen (LRSK).

Wynn, R.B. \& Kastrel, S. 2012. An unprecedented Western Palearctic concentration of Wilson's Storm-petrels Oceanites oceanicus at an oceanic upwelling front offshore Mauritania Seabird 25: 47-53.

\section{Sammanfattning}

Bakgrund

Under sommaren 1988 påbörjades studier av stormsvala på Västkusten, ett nattligt fångst- och ringmärkningsprojekt i skärgården. Det kom att kallas Stormsvaleprojektet och var inspirerat av fynd av stormsvalor som skett några år tidigare utanför Norges sydkust nära gränsen till Sverige. Redan den 29 augusti 1988 fångades en stormsvala på Hermanö, en ö på västsidan av Orust i mellersta Bohuslän. Syftet med studien var att undersöka om 
stormsvalor förekom under presumtiv häckningstid på Västkusten och inte bara vid enstaka tillfällen höst- och vintertid längs kusten vid stormigt väder. Ringmärkning förväntades ge möjligheter att studera flytt- och rörelsemönster utmed kusten samt kartlägga rekryteringsområden och eventuella häckplatser för arten.

Stormsvalan har påträffats åtminstone vid 160 tillfällen i Sverige sedan det första fyndet 17441745, som är både remarkabelt och intressant. Detta vinddrivna första exemplar hittades av en jägare utanför Hedemora i Dalarna och dog en kort tid senare. Fågeln skickades till Linné, som gav den namnet "Stormvädersfogeln, Procellaria pelagica" i sin avhandling Migratiore avium 1745. Några år senare, 1758, fick den sitt ännu gällande vetenskapliga namn, Hydrobates pelagicus (Brolén \& Lönnberg 1935, Figur 1).

\section{Studieområde och metodik}

Verksamheten har i huvudsak ägt rum under perioden 15 juli-30 september på kala öar och vissa utskjutande uddar i skärgården på Västkusten. I Bohuslän har det främst varit i kustområdet vid Hermanö huvud och Måseskär på Orust, och i Halland vid "Gubbanäsan" på Getterön och Ringhals udde (Figur 2 och Figur 4-6).

Fångstförsöken av stormsvalor har skett under lugna nätter med hjälp av slöjnät och bandspelare med inspelade stormsvaleläten. Vid vissa tillfällen har utspilld fiskolja använts som lockmedel. Fångstnäten har som regel placerats nära vattnet i bergsklyftor eller vid klippbranter för att få en mörk bakgrund och undvika att fåglarna ser näten.

Stormsvalorna har vägts till närmaste $0,1 \mathrm{~g}$. Vinglängden har mätts (sträckt vinge enligt W "max", Svensson 2005) liksom tarsens längd samt i vissa fall stjärtlängd, näbb och näbb-nacke. Ruggning och slitage har studerats för att om möjligt kunna åldersbestämma fåglarna. Vi har också noterat om fåglarna spytt upp föda och spelat i nätet. Under den efterföljande undersökningen har vi studerat ruvfläckens utseende med ledning av den klassificering som Scott beskrivit i sin avhandling (1970). Med hjälp av ruvfläckens utseende har vi försökt klarlägga dess utvecklingsstadium för att undersöka om en fågel befinner sig i en aktiv häckningsfas eller inte.

Några stormsvalor även försetts med små radiosändare på $0,69 \mathrm{~g}$ för att kunna pejla rörelsemönster vid fångstlokalerna. För att leta efter häckande stormsvalor har vi tillämpat samma teknik (uppspelning av "purrlätet" i ca 10 sekunder upprepade gånger vid tänkbara bohålor) som använts vid sjöfågelinventeringarna på Brittiska öarna 1998-2002 (Mitchell et al. 2004). Vi har också använt oss av känslig avlyssningsutrustning i bergskrevor och vid jordhålor och spelat upp ungarnas tiggläte för att eventuellt få svar från stormsvalor i bohålor.

Meteorologiska data som salthalt, temperatur, vind- och månförhållanden och eventuell förekomst av uppvällning av bottenvatten har samlats in under perioden 1997-2012 och tillhandahållits av SMHI. SMHI har sedan lång tid dagligen registrerat vind- och vattenförhållanden och uppvällning längs svenska västkusten (Björk \& Nordberg 2003 och SMHI 2012). Det är välkänt att sjöfåglar som stormsvalor attraheras till kustområden med uppvällning, där kallare och näringsrikt havsvatten flödar upp till ytvattnet och koncentrerar zooplankton och mindre bytesdjur och småfiskar i uppvällningszonen.

\section{Resultat}

Sammanlagt har 72 stormsvalor fångats 1988 2012 inom Stormsvaleprojektet. Av dessa har 68 individer ringmärkts av oss, 60 i Bohuslän och 8 i Halland. De övriga fyra stormsvalorna var redan ringmärkta, tre i Norge och en i Skottland. Efter det första fyndet 1988 kom det att dröja åtta år innan nästa stormsvala fångades och ringmärktes. I slutet av 1990-talet fångades en större andel, som mest 13 ex. under toppåret 1999, ett år då det förekom perioder med uppvällning i Kattegatt och Skagerack (Figur 4). Den genomsnittliga fångstfrekvensen under 25-årsperioden (74 fångster under 198 nätter) blev 0,374 fåglar per natt eller omkring tre fåglar per år.

Den tidigaste fångsten har skett den 18 juli (1999) och den senaste den 17 september (2000), men alltför få fångsttillfällen har skett före den 18 juli och efter den 17 september för att kunna utesluta att stormsvalor uppträder längs kusten tidigare eller senare på säsongen (Figur 5). Det har varit en viss koncentration av fångster till augusti månad och en dygnstopp vid midnatt (Figur 5-6). Vädret har varit en begränsande faktor under vissa år med långa perioder av lågtryck och ostadigt väder, vilket resulterat i färre fångsttillfällen än planerat.

Den genomsnittliga vinglängden för samtliga individer var $123,1 \mathrm{~mm}$ (SD 2,57 och variationsbredd $117-130 \mathrm{~mm}, \mathrm{n}=71)$. Vi fann ingen signifikant skillnad mellan de båda åldersgrupperna; Tabell 1a och 1b). Jämfört med flertalet andra studier var vinglängden förhållandevis lång vilket kan 
bero på att mätningen skett med sträckt vinge i vår undersökning.

Vikten varierade mellan 21,1 och 31,5 g (medelv. 25,5 g, SD 1,86, n=68) oavsett ålder; Tabell 1a och 1b). Noterbart är att $21 \%$ (14 ex.) av fåglarna vägde över $27 \mathrm{~g}$ och att några enstaka individer vägde över $30 \mathrm{~g}$, vilket kan tyda på att dessa antingen var adulta individer som intagit rikligt med föda eller att de möjligen hade ägg i kroppen (jmf. Scott 1970) (Tabell 1a, 1b och 2). Av Figur 7 framgår att de tyngsta fåglarnas vikt inte kan förklaras av proportionellt stor längd då endast $19 \%$ av variationen i vikt förklaras av variationen i längd

Tars- och stjärtmått har i vissa avseenden ansetts kunna visa på en skillnad mellan kön och olika åldersgrupper (Cramp 1977). Det fanns inget i vårt material som tydde på någon signifikant skillnad hos dessa eller annan mätt variabel (Tabell 1)

Nitton $(27,5 \%)$ av 69 undersökta stormsvalor uppvisade en rödaktig bar och ådrig ruvfläck utan dun $\mathrm{i}$, vilket skulle kunna tyda på att det är fåglar som uppnått häckningsåldern och sannolikt nyss lämnat en bohåla, dvs. fågeln befinner sig i ett aktivt häckningsstadium (jmf Scott 1970, Tabell 2).

Femtiotvå $(75 \%)$ av 69 fångade stormsvalor "spelade" eller lät i nätet eller i handen i samband med urplockning ur näten och ibland även vid efterföljande ringmärkning (Tabell 2). Vår studie visade i likhet med andra studier att stormsvalor attraheras av stormsvaleläten som spelas upp med hjälp av förstärkt ljudupptagning och högtalare och att fåglarna även reagerar med olika svarsläten. Vi fick inga svar från klippskrevor och andra tänkbara "bohålor" vid uppspelning av "purr- eller churringlätet" vid tänkbara boplatser, som varit en framgångsrik metod vid brittiska inventeringar för att kartlägga häckplatser (Mitchell m.fl. 2004)

Tjugosju (39 \%) av 69 examinerade stormsvalor spydde upp föda, en trandoftande orangefärgad vätska, vilket skulle kunna tyda på att de är individer som uppnått häckningsåldern enligt Scott (1970) (se Tabell 2).

Radiosändare testades några säsonger, men tekniken ställde för stora krav på pejlingsinsatser nattetid och sändarna hade för kort varaktighet och räckvidd. Känsliga mikrofoner testades också, men gav heller inga positiva resultat. Fiskolja testades men om det medförde ökad fångst kunde inte avgöras eftersom vi saknade kontrollgrupp.

Vi har fångat fyra stormsvalor som ringmärkts utomlands, tre i Norge och en i Skottland (Figur $3)$. Inklusive två egna kontroller är andelen redan märkta fåglar på Västkusten omkring $8 \%(6$ av $72)$, vilket är i nivå med vissa norska data (8.1-
12\%). Återfyndsfrekvensen av samtliga fångade och ringmärkta stormsvalor i Stormsvaleprojektet (medräknade även 6 egna ringmärkta stormsvalor som kontrollerats på andra platser) är något högre, ca $18 \%$ (13 av 72 inklusive en fågel kontrollerad två ggr i Norge).

Av de norskmärkta fåglarna som kontrollerades på västkusten var en ringmärkt vid Klepp i Rogaland $(58.45 \mathrm{~N} 05.30 \mathrm{E}) \mathrm{i}$ södra Norge och en vid Namsos i Nordtröndelag (64.37N 11.30E) i mellersta Norge och en på Hernyken vid Röst på Lofoten (67.26N 11.52E). Samtliga fåglar fångades på Måseskär i mellersta Bohuslän, och avståndet till Röst är $1038 \mathrm{~km}$. Den brittiska stormsvalan var märkt den 27 juli 2006 på Sanday, Tres Ness på Orkney (59.13N 02.30E) och kontrollerades även den på Måseskär den 5 augusti samma år (Figur 3).

Sex stormsvalor har ringmärkts på svenska västkusten, samtliga på Måseskär, och sedan fångats och kontrollerats utomlands, fem i Norge (varav en två gånger) och två på de Brittiska öarna. En av fåglarna fångades på Fuglenyken i Nordland (68.47N 11.26.E), ett avstånd på 1200 km till Måseskär. Ytterligare en fågel kontrollerades i Nordnorge, på Hernyken i Lofoten (se ovan). Två fåglar återfångades i södra Norge, vid Fejde i Hordaland $(60.46 \mathrm{~N}$ och $04.42 \mathrm{E})$ och vid Eigersund i SörRogaland (58.22N 06.03E). Den stormsvala som fångades och kontrollerades på Hernyken hade två år tidigare (en månad efter ringmärkningstillfället) även blivit kontrollerad vid Kråkenäs i mellersta Norge, men ringnumret blev felaktigt avläst (slutsiffran 6 blev avläst som 9), vilket var ett ringnummer i vår serie som ännu inte blivit använt vid det tillfället, och har därför inte blivit registrerat som ett officiellt återfynd. Två stormsvalor kontrollerades i norra Skottland, den ena vid Faraid Head i Highland region $(58.36 \mathrm{~N}$ 04.47E) och den andra vid Sanday på Orkney (se ovan) (Figur 3). En stormsvala som märktes på Måseskär 1999, dök upp igen nästan ett år senare, men denna gång lite längre norrut på Västkusten, på Torsö i Väderöarkipelagen. Ytterligare en fågel som fångades 2009 på västsidan av Måseskär återfångades flera timmar senare i ett annat nät på nordsidan av ön.

\section{Diskussion}

Vid jämförelse med andra studerade populationer av stormsvalor var den genomsnittliga uppmätta vinglängden förhållandevis lång $\mathrm{i}$ vår studie (W"max" enligt Svensson 2005); 123,1 mm (95 \% konfidensintervall för medel värdet mellan 122,49123,69, n=71), vilket kan jämföras med 120,0 
$\mathrm{mm}$ för häckpopulationen vid Skokholm ( $\mathrm{sd}=2,2$ $\mathrm{n}=1302$, Scott 1975) och $120 \mathrm{~mm}$ för en häckpopulationen i England (Cramp 1977) samt 123,5 mm $(n=22)$ i augusti och $121,81 \mathrm{~mm}(\mathrm{n}=27)$ i oktober för populationerna på Hernyken vid Lofoten 1989. De olika mätresultaten kan bero på individuella skillnader i mätmetod och olika fördelning mellan häckande och kringvandrande icke-häckande stormsvalor i respektive populationsstudie.

Scott angav i sin studie att två och tre år gamla fåglar ännu inte uppnått full kroppsstorlek och inte heller helt utvuxen vinglängd. De har en signifikant kortare vinglängd än äldre och könsmogna individer, i genomsnitt 0,82 m.m. kortare. Detta har vi inte kunnat visa $i$ vårt relativt begränsade material. Bolton och Thomas revidering av ruggnings- och ålderskriterierna 2001 har underlättat åldersbestämningen av stormsvalor. Från säsongen 2002 började vi tillämpa dessa kriterier i vår studie, vilket sannolikt har inneburit en något säkrare åldersbestämning av stormsvalor från säsongen 2002 $i$ våra studier.

Den genomsnittliga kroppsvikten hos samtliga ringmärkta stormsvalor på Västkusten var förhållandevis låg, 25,5 g, vilket överensstämmer med medelvikten för icke-häckande fåglar, 25,3 g i Scotts undersökningar på Skokholm (1970). Där var medelvikten klart högre för könsmogna vuxna fåglar, 27,6 g. Enligt Scott lägger icke häckande kringvandrande fåglar inte upp fettreserver på samma sätt som häckande fåglar inför häckningssäsongen. De icke-häckande fåglarna på Skokholm var därför genomgående ca 1,5-2,5 g lättare sett över hela säsongen än häckande individer. Viktfördelningen i vår undersökning kan tyda på att det råder en dominans av icke häckande kringvandrande stormsvalor på Västkusten.

Brittiska studier har visat att kringvandrande icke könsmogna stormsvalor lättare lockas i näten än adulta häckande fåglar (Harris et al. 1993). Det har framkommit vid uppföljande studier av ringmärkta stormsvaleungar att återfångstfrekvensen successivt avtar mellan två och fem års ålder och sedan i princip upphör helt (Okill \& Bolton 2005). Nedgången i återfångstfrekvensen visar i dessa studier att stormsvalorna efterhand antingen dör eller lämnar den kringvandrande populationen och rekryteras som häckande fåglar. Det är svårt att avgöra om kategorin fångade stormsvalor på Västkusten med förhållandevis hög kroppsvikt och välutvecklad ruvfläck (19 \% eller ungefär var femte fångad fågel) utgör adulta könsmogna fåglar i aktivt häckningsskede eller tillhör kategorin kringvandrande icke häckande fåglar. Ruvfläckens utseende liknar och motsvarar sannolikt de ruvfläcksstadier som Scott i sin avhandling (1970) rubricerade som antingen "highly vascularized with systems of dilated blood vessels" (typ vi) eller som "highly vascularized with greatly distended blood vessels with knotted appearance" (typ vii). Enligt Scott kan ingen fågel med dessa kriterier säkert klassas som häckande, men det är en indikation på att det är en fågel som tagit en bohåla i besittning. Kringvandrande icke häckande fåglar kan även förekomma på häckplatser och uppvisa välutvecklade röda, ådriga ruvfläckar med likartat utseende (andelen av denna kategori som tagit en bohåla i besittning är ca $30 \%$ på Skokholm enligt Scott).

Fåglarna rör sig även över stora avstånd vid födosök och Måseskär ligger strategiskt till på Västkusten där den Jutska havsströmmen går in mot Västkusten och möter den baltiska havsströmmen. Ön ligger i ett näringsrikt och fiskrikt kustområde som även tidvis torde kunna attrahera tillfälligt födosökande stormsvalor, som följer dessa strömmar. Studier har visat att signifikant fler havssulor och alkekungar påträffades $\mathrm{i}$ uppvällningsbälten $\mathrm{i}$ Skagerack under särskilda hydrologiska förhållanden och under olika tider på året (Skov \& Durick 2000). Ett ökat antal uppvällningar registrerades i Kattegatt och Skagerack under 1999, det år då även flest stormsvalor fångades mellan 1988 och 2012.

\section{Slutsats}

Det är tveksamt om det finns häckande stormsvalor på Västkusten i Sverige på grundval av hittills utförda studier. Möjligen skulle häckning kunna ske vissa år, under extremt gynnsamma förhållanden, t.ex. år med långa perioder av uppvällning av näringsrikt vatten från havsströmmarna. Inventeringar av stormsvala längs Västkusten har visat att det, vid jämförelse med kända häcklokaler utomlands, finns platser som skulle kunna utgöra tänkbara häckningslokaler för stormsvala.

Noterbart är att det förekommer stormsvalor dagtid under stormigt väder, särskilt under hösten (sammanlagt över 160 observationer i Sverige). Det är dock helt klart att det regelbundet förekommer eller passerar stormsvalor på svenska västkusten under presumtiv häckningstid, från mitten av juli till slutet av september. 


\section{Appendix 1}

Erik Aspegren har studerat och ringmärkt stormsvalor på Hernyken vid Lofoten sedan 1970-talet. Genom sin fångst av en stormsvala 1987 på Akeröya vid norska kusten nära gränsen till Sverige inspirerade han oss att börja undersöka en eventuell förekomst av stormsvalor på svenska Västkusten. Han medverkade även vid några fångstförsök $\mathrm{i}$ Sverige, bl.a. på Nordkoster och på Måseskär i Bohuslän samt vid Ringhals udde i Halland. Han bjöd även in oss att besöka och ringmärka stormsvalor och klykstjärtade stormsvalor på Lofoten, där vi också deltog i ett lunnefågelprojekt på Hernyken. Erik Aspegren kom från Nesoddtangen utanför Oslo och gick bort 1999.

Erik Aspegren ringed Storm Petrels at Hernyken in the Lofoten Islands since 1970. His capture of a Storm Petrel 1987 in Akeröya on the Norwegian coast close to the Swedish border inspired us to examine possible occurrence of Storm Petrels along the west-coast of Sweden. He participated in some of our initial efforts at the North Koster Islands, Måseskär, and the Ringhals peninsula. He invited us to visit and ring Storm Petrels and Leach's Petrels in the Lofotens Islands, where we also assisted in the Puffin research. Erik Aspegren lived at Nesoddtangen at the outskirt of Oslo and passed away in 1999.

\section{Appendix 2}

Roland Börjesson var en av initiativtagarna till Stormsvaleprojektet på Västkusten och var drivande i projektet och medverkade entusiastiskt varje år från starten 1988 ända fram till sin död 2011 . Han var född 1932. Han var särskilt engagerad av nattaktiva fåglar och deltog även aktivt i olika uggleprojekt, bl.a. Berguv sydväst och verkade främst i Bohuslän på Västkusten

Roland Börjesson was one of the initiators of the Storm Petrel project at the Swedish west-coast and one of the driving forces and participated with great enthusiasm from the very beginning 1988 to his death 2011. He was born 1932. He was especially engaged in night active birds and owl projects, among others the Great Horned Owl Southwest. Most of his work was done in Bohuslän at the Swedish west coast. 